\title{
Mutual Adsorption of Lead and Phosphorus onto Selected Soil Clay Minerals
}

\author{
Mohammed Abdalla Elsheikh1,2,3*, Pardon Muchaonyerwa², Erni Johan1, Naoto Matsue1, \\ Teruo Henmi ${ }^{1}$ \\ ${ }^{1}$ Department of Life Environmental Conservation, Faculty of Agriculture, Ehime University, Matsuyama, Japan \\ ${ }^{2}$ School of Agricultural, Earth and Environmental Sciences, University of KwaZulu-Natal, Pietermaritzburg, South Africa \\ ${ }^{3}$ Department of Soil and Environment Sciences, Faculty of Agriculture, University of Khartoum, Khartoum, Sudan \\ Email: *mohmedelsheikh@gmail.com
}

How to cite this paper: Elsheikh, M.A., Muchaonyerwa, P., Johan, E., Matsue, N. and Henmi, T. (2018) Mutual Adsorption of Lead and Phosphorus onto Selected Soil Clay Minerals. Advances in Chemical Engineering and Science, 8, 67-81.

https://doi.org/10.4236/aces.2018.82005

Received: January 30, 2018

Accepted: April 7, 2018

Published: April 10, 2018

Copyright $\odot 2018$ by authors and Scientific Research Publishing Inc. This work is licensed under the Creative Commons Attribution International License (CC BY 4.0).

http://creativecommons.org/licenses/by/4.0/

c) (i) Open Access

\begin{abstract}
Mutual adsorption of lead $(\mathrm{Pb})$ and phosphorus $(\mathrm{P})$ at $\mathrm{pH} 5$ onto three soil clays materials (kaolinite, montmorillonite, and allophane) was studied to know interaction of the anion and the cation at surface of the clays. Adsorption of $\mathrm{Pb}$ was determined on montmorillonite, kaolinite and allophane with the following pretreatments; 1) untreated clay (control), 2) phosphate treated clay (P-clay) and 3) clay pre-treated with both $\mathrm{P}$ and $\mathrm{Pb}(\mathrm{P}$-Pb-clay). Adsorption of $\mathrm{P}$ was determined on montmorillonite, kaolinite and allophane with the following pretreatments; 1) control 2) $\mathrm{Pb}$ treated clay ( $\mathrm{Pb}$-clay) and 3) $\mathrm{P}-\mathrm{Pb}$-clay. The adsorption of $\mathrm{Pb}$ on the untreated clays was in the order: montmorillonite $>$ allophane $>$ kaolinite. On allophane and kaolinite $\mathrm{Pb}$ adsorption was in the order P-clay $>\mathrm{P}$-Pb-clay $>$ control. For montmorillonite, the trend was: $\mathrm{P}-\mathrm{Pb}$-clay $=$ control $>\mathrm{P}$-clay. Phosphorus adsorption was in the order $\mathrm{Pb}$-clay $=\mathrm{P}$-Pb-clay $>$ control for montmorillonite and kaolinite, $\mathrm{Pb}$-clay $>$ control $>\mathrm{P}$-Pb-clay for allophane. The findings suggested that pre-treatment with phosphate increases $\mathrm{Pb}$ adsorption on kaolinite and allophane, and decrease on montmorillonite, while pretreatment with $\mathrm{Pb}$ increases phosphate sorption on all clays, and both $\mathrm{Pb}$ and $\mathrm{P}$ increased adsorption on montmorillonite and kaolinite and decrease on allophane.
\end{abstract}

\section{Keywords}

Allophane, Kaolinite, Montmorillonite, Mutual Adsorption, Lead and Phosphorus

\section{Introduction}

Heavy metals are among the major contaminants of the environment, with se- 
rious effects on animal and human health [1]. Lead is among the most toxic heavy metals, even at low concentrations, to animals and human beings. Although $\mathrm{Pb}$ naturally occurs at low concentrations in the earth's crust, volcanic activity, weathering and erosion of the soil materials [2] and anthropogenic activities such as coal burning, mine tailings, metalmelting and emission from car-exhaust cause serious environmental pollution with $\mathrm{Pb}$ [2] [3]. Addition to this, although $\mathrm{Pb}$ is not toxic to plants, its accumulation in tissue of plants growing on polluted soil could have serious consequences on animal and human health. These effects depend on the availability of $\mathrm{Pb}$ in the soil, which is affected by adsorption and desorption of the metal on the surfaces of soil colloids.

Montmorillonite is one of the most abundant clay minerals in soils, especially those that are not highly weathered and is potential binding agent for pollutants as a result of its high specific surface area and cation exchange capacity [4] [5]. On the other hand, kaolinite is a clay mineral that is abundant in highly weathered soils like Ultisols and Oxisols, in association with oxides of iron (Fe) and aluminum (Al) [4] [5]. Allophane is a unique clay mineral that is abundant in weathered volcanic ash soils, and is a principal material of clay fraction in andisols and podzols. The wall structure of as nano-ball allophane has been proposed as aluminm-nesosilicate structure composed of curved gibbsite sheet with monomeric $\mathrm{SiO}_{4}$ tetrahedral attached to it [6]. The surface activity of these colloids contributes in the adsorption and immobilization of contaminants in soil.

The interaction between toxic metals and clay mineral colloids is important in surface chemistry, soil science, and pollution studies [7] [8] [9]. For example, the interaction between phosphate and soil minerals affects the surface activity of the colloid and mobility of $\mathrm{P}$ in the soil. Hence, adsorption of heavy metals on soil minerals could be affected by the presence of phosphate ions in the soil system. Extensive studies have been conducted to investigate the possibility of using phosphate to reduce mobility and bioavailability of heavy metals in soils and clay materials [10] [11] [12]. Based on work by [13] and [14], the pretreatment of soils with phosphate is now a widely accepted technique to remediate soils and solid waste contaminated with $\mathrm{Pb}$. Recently there have been studies conducted on the adsorption of $\mathrm{Pb}$ on kaolinite pretreated with phosphate [15] [16] [17]. However, there is a paucity of studies on mutual adsorption on $\mathrm{Pb}$ and phosphate on montmorillonite and allophane, which are among the most important colloids, is soils. Therefore, the objective of this study was to investigate the effect of mutual adsorption of $\mathrm{Pb}$ and phosphate by montmorillonite, kaolinite and allophane.

\section{Material and Methods}

\subsection{Clay Minerals}

Montmorillonite (JCSS-3101) and kaolinite (JCSS-1101) samples used in this study were supplied by the Clay Science Society of Japan. Na-montmorillonite and Na-kaolinite were prepared by saturating the clay samples with sodium 
(Na). The clay samples were washed three times with $1 \mathrm{M} \mathrm{NaCl}$ followed by washing with $80 \%$ methanol until $\mathrm{Cl}^{-}$free and finally with acetone and air-dried. Pumice grains containing nano-ball allophane were collected from a volcanic ash soil from Kakino, Kumamoto prefecture, Japan. In order to obtain the pure nano-ball allophane, free from contaminants such as imogolite, volcanic glass, and opaline silica, only the inner portion of the pumice grains was used [18]. The fraction with less than $0.2 \mu \mathrm{m}$ equivalent diameter was separated by centrifugation after ultrasonification at $28 \mathrm{kHz}$ and dispersion at $\mathrm{pH} 10$. The collected sample was flocculated by saturation $\mathrm{NaCl}$ solution and washed with water, then stored as suspension at pH 6 in $10 \mathrm{mM} \mathrm{NaCl}$. The prepared allophane was subjected to X-ray diffractometry, infrared spectroscopy, and thermal analysis, and was proven to be free from contaminants. The $\mathrm{Si} / \mathrm{Al}$ ratio of allophane used was determined by the acid oxalate method [19] as 0.99 , and contents of the other metals except for $\mathrm{Na}$ were negligible. The allophane was the high $\mathrm{Si} / \mathrm{Al}$ type [18].

\subsection{Preparation of Clays}

Phosphate pre-treatment of the clays was done by mixing the clays $(0.5 \mathrm{~g}$ for kaolinite and $0.1 \mathrm{~g}$ for both montmorillonite and allophane), with $1.0 \mathrm{mM}$ $\mathrm{NaH}_{2} \mathrm{PO}_{4}$ using $10 \mathrm{mM} \mathrm{NaNO}_{3}$ as a background electrolyte solution and water to reach a final volume of $100 \mathrm{~mL}$. As kaolinite was expected to be less reactive than montmorillonite and allophane, higher solid to solution ratio $(0.5 \mathrm{~g}: 100 \mathrm{~mL})$ was used. Solution $\mathrm{pH}$ was maintained at $\mathrm{pH} 5$ by addition of $0.1 \mathrm{M} \mathrm{NaOH}$ or $0.1 \mathrm{M} \mathrm{HNO}_{3}$ during the course of the experiment. The suspensions were shaken on a reciprocal shaker for $24 \mathrm{~h}$ followed by centrifuging at $8000 \mathrm{rpm}$ for $25 \mathrm{~min}$. The samples were washed with water to remove excess $\mathrm{NaH}_{2} \mathrm{PO}_{4}$. The phosphate-clays (P-montmorillonite, $\mathrm{P}$-kaolinite and $\mathrm{P}$-allophane) were immediately used in the form of wet paste in experiments with $\mathrm{Pb}$. Clays pretreated with both $\mathrm{P}$ and $\mathrm{Pb}$ were prepared by simultaneous addition of $\mathrm{P}$ and $\mathrm{Pb}$, by mixing clays (kaolinite $(0.5 \mathrm{~g})$ and montmorillonite and allophane $(0.1 \mathrm{~g})$, with $1.0 \mathrm{mM}$ $\mathrm{NaH}_{2} \mathrm{PO}_{4}$ and $1.0 \mathrm{mM} \mathrm{Pb}\left(\mathrm{NO}_{3}\right)_{2}$ (equimolar solutions), with $10 \mathrm{mM} \mathrm{NaNO}_{3}$ as the background electrolyte at $\mathrm{pH}$. The suspensions were shaken on a reciprocal shaker for $24 \mathrm{~h}$ followed by centrifuging at $8000 \mathrm{rpm}$ for $25 \mathrm{~min}$. The samples were then washed with water to remove excess $\mathrm{Pb}\left(\mathrm{NO}_{3}\right)_{2}$. The treated clays ( $\mathrm{P}-\mathrm{Pb}$-montmorillonite, $\mathrm{P}$-Pb-kaolinite and $\mathrm{P}-\mathrm{Pb}$-allophane) were immediately used in the form of wet paste in the experiments.

Lead pre-treatment of the clays was done exactly the same as for phosphate pretreated clays, except that $1.0 \mathrm{mM} \mathrm{NaH} \mathrm{PO}_{4}$ was replaced with $1.0 \mathrm{mM}$ $\mathrm{Pb}\left(\mathrm{NO}_{3}\right)_{2}$. The $\mathrm{Pb}$-clays ( $\mathrm{Pb}$-montmorillonite, $\mathrm{Pb}$-kaolinite and $\mathrm{Pb}$-allophane) were immediately used in the form of wet paste in experiments with P. Control clays (montmorillonite, kaolinite and allophane) were prepared in the same way with the background electrolyte and water, but without added $\mathrm{P}$ or $\mathrm{Pb}$. The treated and control clays were then used in batch adsorption experiments. 


\subsection{Lead Adsorption}

Adsorption of $\mathrm{Pb}$ on treated montmorillonite was achieved by adding a series of initial $\mathrm{Pb}$ up to $1 \mathrm{mM}$ to the wet pastes of clay 1 ) pre-treated with phosphate 2) pretreated with both phosphate and $\mathrm{Pb}$ and 3 ) with no phosphate nor $\mathrm{Pb}$ (control clay). The treatments were in duplicate. The suspensions were shaken on a reciprocal shaker for $24 \mathrm{~h}$, at $20^{\circ} \mathrm{C} \pm 2^{\circ} \mathrm{C}$, before centrifugation at $8000 \mathrm{rpm}$ for $25 \mathrm{~min}$. The supernatant was carefully decanted and analyzed for $\mathrm{Pb}$ concentration by atomic absorption spectrophotometer. The amounts of $\mathrm{Pb}$ adsorbed were calculated from the difference between initial and final concentrations, and plotted against solution concentration at equilibrium. The same study was repeated with 1) kaolinite and 2) allophane with the same treatments.

\subsection{Phosphate Adsorption}

Adsorption of phosphate on treated montmorillonite was achieved by adding a series of initial phosphate up to $1 \mathrm{mM}$ to the we pastes of clay 1) pre-treated with $\mathrm{Pb}$ 2) pretreated with both phosphate and $\mathrm{Pb}$ and 3) with no phosphate nor $\mathrm{Pb}$ (control clay). The suspensions were shaken on a reciprocal shaker for $24 \mathrm{~h}$ before centrifugation at $8000 \mathrm{rpm}$ for $25 \mathrm{~min}$. Phosphate in the supernatant was analyzed colorimetrically by the ascorbic molybdate method [20]. The amounts of phosphate adsorbed were calculated from the difference between initial and final concentrations, and plotted against solution concentration at equilibrium. The same study was repeated with kaolinite and allophane with the same treatments. The adsorption data were fitted to the Langmuir equation and sorption parameters calculated with the linearized equation (Equation (1)).

$$
C / X=1 / X_{m} K+C / X_{m}
$$

where $X=$ amount of $\mathrm{Pb}$ adsorption $\left(\mu \mathrm{mol} \cdot \mathrm{g}^{-1}\right), K=$ a constant related to binding energy $\left(\mathrm{L} \cdot \mu \mathrm{mol} \cdot \mathrm{L}^{-1}\right), X_{m}=$ maximum $\mathrm{Pb}$ adsorption $\left(\mu \mathrm{mol} \cdot \mathrm{g}^{-1}\right), C=$ equilibrium $\mathrm{Pb}$ concentration $\left(\mu \mathrm{mol} \cdot \mathrm{L}^{-1}\right)$.

\section{Results and Discussion}

\subsection{Lead Sorption}

The adsorption isotherms of $\mathrm{Pb}$ on three sorbents (montmorillonite, allophane, and kaolinite) at $\mathrm{pH} 5$ are shown in Figures $1-3$. The $\mathrm{Pb}$ adsorption increased with increasing $\mathrm{Pb}$ concentration in all cases. The curves for allophane were obtained with the same solid/solution ratio as that used for montmorillonite $(0.1 \mathrm{~g}$ : $100 \mathrm{ml}$ ). Adsorption isotherms of $\mathrm{Pb}$ by three clays mineral demonstrate differences in adsorption capacity (Figures 1-3). The component could be classified according to their adsorption capacity: montmorillonite $>$ allophane $>$ kaolinite, as inferred by their CEC values. Similar results were obtained by other authors who study the adsorption of $\mathrm{Pb}$ by soil in different cation exchange capacity [21] and in cadmium [22] and nickel [23] and in zinc [24]. The results indicating that the montmorillonite and allophane are important sinks for heavy 


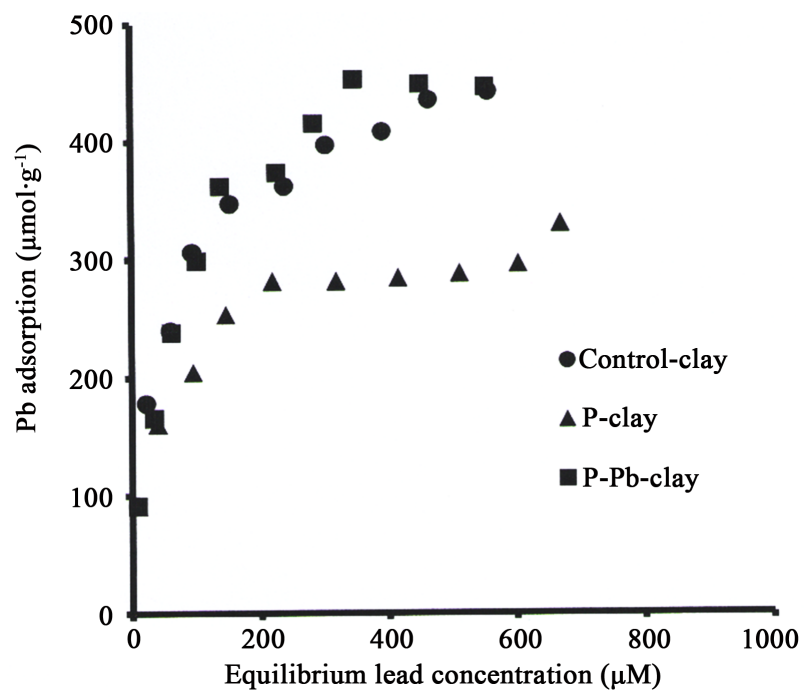

Figure 1. Lead adsorption isotherm on montmorillonite (control), P-montmorillonite and $\mathrm{P}-\mathrm{Pb}$-montmorillonite.

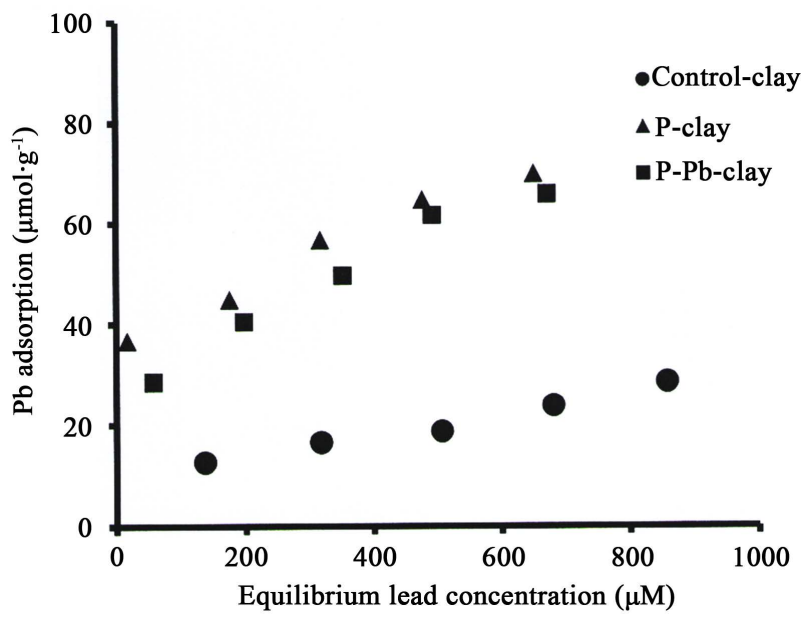

Figure 2. Lead Adsorption isotherm on kaolinite (control), P-kaolinite and P-Pb-kaolinite.

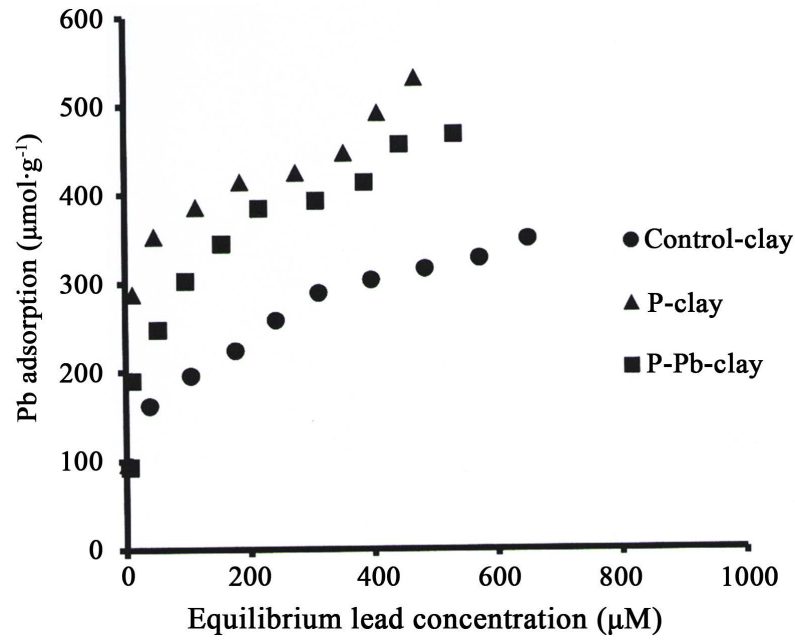

Figure 3. Lead adsorption isotherm on allophane (control), P-allophane and P-Pb-allophane. 
metals in soils, due to the fact that they have a large specific surface area. However, kaolinite has a low CEC and, therefore, it is not expected to be an ion-exchanger of high order. The adsorption isotherms of $\mathrm{Pb}$ on all three minerals followed Langmuir type. The Langmuir equation parameters are summarized in Table 1. The trends of the $\mathrm{Pb}$ sorption isotherms and maximum adsorption on allophane were similar to those of kaolinite. Among all the three minerals, kaolinite had a lower $\mathrm{Pb}$ sorption than montmorillonite and allophane which had a similar order of magnitude. The maximum adsorption capacity of $\mathrm{Pb}$ in three minerals was in the order: montmorillonite > allophane $>$ kaolinite. Montmorillonite has high $\mathrm{Pb}$ adsorption because it has high cation exchange capacity compare with allophane and kaolinite [25] [26]. Adsorption of $\mathrm{Pb}$ on kaolinite has been shown to involve both permanent and variable charge sites [27]. [28] and [29] showed significant inner sphere complexation of $\mathrm{Pb}$ on kaolinite. Using synchrotron X-ray absorption fine structure spectroscopy study demonstrates the $\mathrm{Pb}$ adsorption mostly the inner sphere, probably monodentate $\mathrm{Pb}$ complexation at aluminum-oxide surfaces [30]. Figure 3 shows that the $\mathrm{Pb}$ strongly adsorbed on nano ball allophane. Allophane was found to adsorb various cations and anions depending upon $\mathrm{pH}$ of the soil, cations being adsorbed mostly in high $\mathrm{pH}$ silanol groups (negative charges $\left(\mathrm{Si}-\mathrm{O}^{-}\right)$at inner surface of the ball). Anions adsorbed at positive charge $\left(\mathrm{Al}-\mathrm{OH}_{2}^{+}\right)$at low $\mathrm{pH}$ at pore sites of the ball of allophane. The allophane strongly adsorbed $\mathrm{Pb}$, this may be $\mathrm{Pb}$ ions that were strongly attracted to dissociated silanol group at the inner surface of hallow spherical of nano-ball allophane particle. Molecular orbital calculations with MOPAC AMI basis set indicated that could adsorbed not only on dissociated silanol groups but also with the undissociated silanol groups. The calculations also indicated that when metal ions interacted with undissociated silanol groups, dissociation reaction of the silanol groups accelerated [31].

Table 1. Maximum adsorption $\left(X_{m}\right)$ and binding energy $(K)$ for lead on the three minerals as affected by pre-treatment.

\begin{tabular}{ccccc}
\hline Mineral & Parameter & Control-clay & P-clay & P-Pb-clay \\
\hline \multirow{2}{*}{ Montmorillonite } & $X_{m}$ & 500 & 322.6 & 500 \\
& $K$ & 0.015 & 0.023 & 0.0168 \\
& $R^{2}$ & 0.99 & 0.99 & 0.99 \\
\hline Allophane & $X_{m}$ & 370.4 & 500 & 476.2 \\
& $K$ & 0.014 & 0.041 & 0.0225 \\
& $R^{2}$ & 0.98 & 0.98 & 0.99 \\
Kaolinite & $X_{m}$ & 37.5 & 74.1 & 78.1 \\
& $K$ & 0.0027 & 0.015 & 0.0674 \\
& $R^{2}$ & 0.89 & 0.97 & 0.97
\end{tabular}


The adsorption isotherm of $\mathrm{Pb}$ onto phosphate-pretreated (phosphate adsorbed on clays first then $\mathrm{Pb}$ adsorbed to clay surface) by three clays mineral samples as shown in Figures 1-3. These isotherms represent the adsorption behaviorsof $\mathrm{Pb}$ on kaolinite and allophane were similar to each other, the amount of $\mathrm{Pb}$ was higher as compared with clay free phosphate. Both are different from $\mathrm{Pb}$ adsorption amount by montmorillonite. Adsorption of $\mathrm{Pb}$ onto clay minerals can occur through two mechanisms: the first, via outer-sphere adsorption, which occurs primarily on basal planes existing in the interlayer of the clay mineral, and the second, via inner-sphere adsorption, which occurs at the amphoteric ligand sites existing on the edges of clay minerals [32] [33] [34] [35]. The adsorption of $\mathrm{Pb}$ by montmorillonite at low-ionic-strength occur is consistent with outer-sphere complexation [35]. The phosphate reduced $\mathrm{Pb}$ adsorption on montmorillonite, these attributed to the adsorbed phosphate which partially prevented the added $\mathrm{Pb}$ penetrating into the interlayer space of montmorillonite, thus, the phosphate can decrease the interlayer of adsorption for $\mathrm{Pb}$ [36]. On another hand, phosphate can also lower surface electrostatic potential near the solid surface and therefore, enhance the $\mathrm{Pb}$ uptake through outer layer complexes [36]. However, this description does not mean that the adsorption of $\mathrm{Pb}$ only occurs as inner-sphere complexes. The adsorption of phosphate causing the increasing in soil negative charge [15] [37] [38]. Kaolinite pretreated with P provides an ideal surface for the metal to specifically react with the P moiety bound to aluminum oxide sorption sites on the surface. Phosphate would increase soil adsorption for heavy metal with positive charges [39]. This was a demonstration for $\mathrm{Pb}$ on $\mathrm{P}$-allophane and also for P-kaolinite in this study. Similar results were found on adsorption of $\mathrm{Pb}$ on P-kaolinite [15] [16] [17]. The phenomena also supported by many workers in different mineral for example in P-pretreated goethite [11]. It was suggested that enhanced cadmium adsorption was caused by the reduction of the zero point of charge of goethite and surface potential after phosphate adsorption. The study also adopts that the rise in cadmium adsorption on goethite may happen because of a decrease in the electrostatic potential near the solid surface, which arises with the increase in negative charge. Moreover, another possibile explanation was stated by [40] [41] they detected pyromorphite formation, and the pyromorphite was responsible for removal of $\mathrm{Pb}$ from solution. The precipitation of pyromorphite in suspension was detected by XRD and identified by both SEM and EBSD.

Furthermore, the simultaneously $\mathrm{Pb}$-P-treated clay was given different amounts of $\mathrm{Pb}$ adsorption when compared with the $\mathrm{Pb}$ adsorption in $\mathrm{P}$-treatment mineral (Figures 1-3). Phosphorus-pre-treated montmorillonite had a lower $\mathrm{Pb}$ sorption than $\mathrm{P}$-free and that simultaneously pre-treated with $\mathrm{P}$ and $\mathrm{Pb}$ (Figure 1 and Table 1). As shown in these figures, the amount of $\mathrm{Pb}$ in the simultaneously $\mathrm{Pb}$-P-treated clay was slightly lower than that $\mathrm{P}$-mineral, in all cases. In the same time, the simultaneously $\mathrm{Pb}-\mathrm{P}$-montmorillonite was equal to montmorillonite free-phosphate (Figure 1). The may be attributed to $\mathrm{Pb}$-phosphate in 
the simultaneous system forming a different complex solution from the pretreated system. Therefore, in the simultaneously treated system, these complexes might be adsorbed by some sorption sites that differed from the $\mathrm{Pb}$ adsorbing sites. Moreover, as shown in Table 1 , the Xm of $500 \mathrm{mmol} \cdot \mathrm{kg}^{-1}$ on montmorillonite free phosphate and $322.2 \mathrm{mmol} \cdot \mathrm{kg}^{-1}$ on P-pretreated clay. The lower Xm value on P-pretreated clay was due to the adsorbed phosphate which partially prevented the added $\mathrm{Pb}$ penetrating into the interlayer space of montmorillonite. Nevertheless, in the simultaneous experiments, Xm did not decrease (500 mmol. $\left.\mathrm{kg}^{-1}\right)$, indicating want of kinetic study of the two adsorbates on montmorillonite.

\subsection{Adsorption of Phosphate}

The adsorption isotherms of $\mathrm{P}$ on the three clays mineral samples are shown in Figures 4-6. The P sorption increased with increases of phosphate concentration in all cases. Like for $\mathrm{Pb}$ adsorption, phosphate adsorption isotherms on all three minerals followed the Langmuir type. The Langmuir equation parameters are summarized in Table 2. Adsorption isotherms for phosphate onto the three clays mineral samples exhibited differences in adsorption capacity (Figures 4-6). The components could be classified according to their adsorption capacity: allophane $>$ kaolinite $>$ montmorillonite, indicating that allophane is strong adsorbed phosphate. The adsorption of phosphate has been extensively investigated by former workers [37] [42]. The phosphate anion is easily adsorbed on allophonic soils [43] and very strongly adsorbed on the natural nano-ball allophane [44] [45] [46]. The allophane has higher affinity to adsorbed phosphate compare with montmorillonite and kaolinite as of the allophane much of $\mathrm{Al}-\mathrm{OH}$ and $\mathrm{Al}-\mathrm{H}_{2} \mathrm{O}$ functional groups on the mineral surface [47]. Aluminol groups, $\mathrm{Al}-\mathrm{OH}$ or $\mathrm{Al}-\mathrm{OH}_{2}$, are responsible for phosphate and organic anions adsorptions in soils and clay minerals [37]. In the structure of allophane, the aluminol groups are only located at the pores of the wall of the hollow spherules [48].

Table 2. Maximum adsorption $\left(X_{m}\right)$ and binding energy $(K)$ for phosphate on the three minerals as affected by pre-treatment.

\begin{tabular}{ccccc}
\hline Mineral & Parameter & Control-clay & Pb-clay & P-Pb-clay \\
\hline \multirow{3}{*}{ Montmorillonite } & $X_{m}$ & 144.9 & 384.6 & 140.8 \\
& $K$ & 0.002 & 0.0485 & 0.005 \\
& $R^{2}$ & 0.94 & 0.99 & 0.88 \\
\hline \multirow{2}{*}{ Allophane } & $X_{m}$ & 322.6 & 416.7 & 222.2 \\
& $K$ & 0.01 & 0.0279 & 0.0032 \\
& $R^{2}$ & 0.98 & 0.99 & 0.97 \\
\hline \multirow{2}{*}{ Kaolinite } & $X_{m}$ & 106.4 & 122.0 & 145 \\
& $K$ & 0.009 & 0.0217 & 0.014 \\
& $R^{2}$ & 0.97 & 0.97 & 0.97 \\
\hline
\end{tabular}




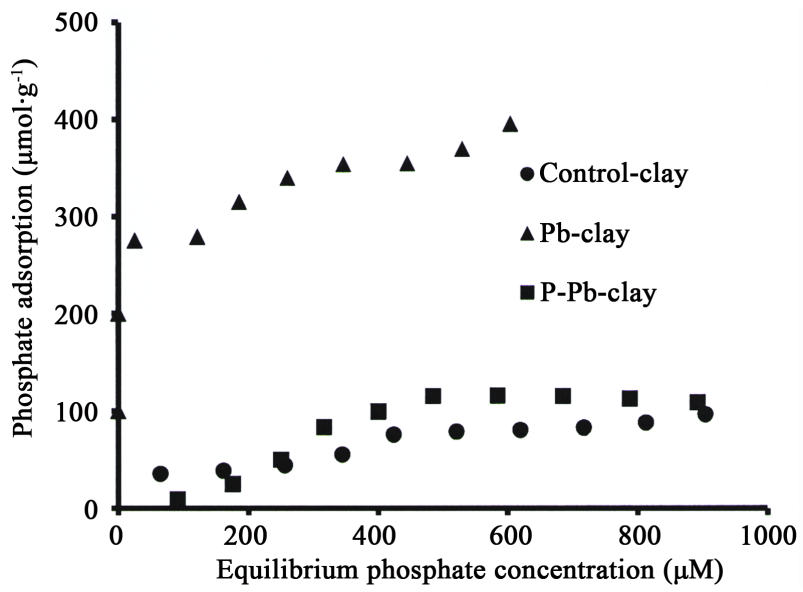

Figure 4. Phosphate adsorption isotherm by montmorillonite (control), $\mathrm{Pb}$-montmorillonite and $\mathrm{P}-\mathrm{Pb}$-montmorillonite.

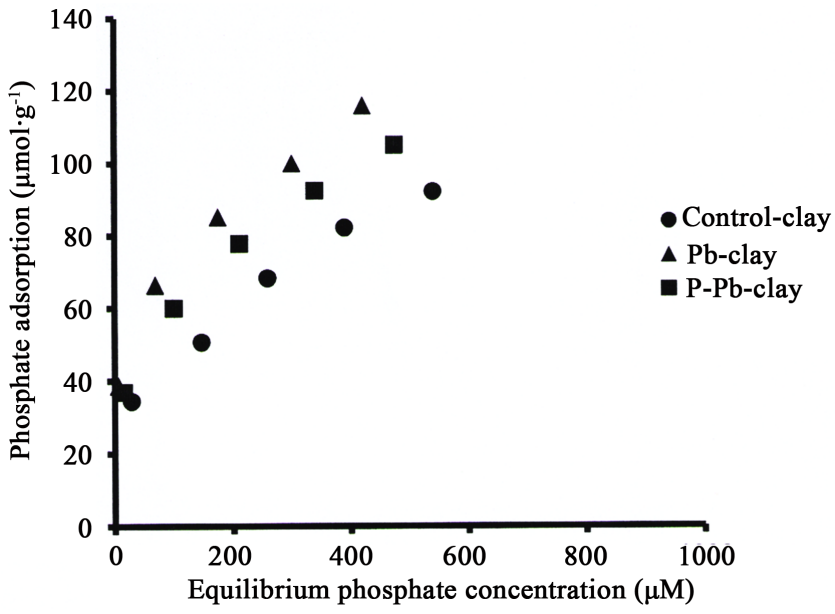

Figure 5. Phosphate adsorption isotherm on kaolinite (control), Pb-kaolinite and $\mathrm{P}-\mathrm{Pb}$-kaolinite.

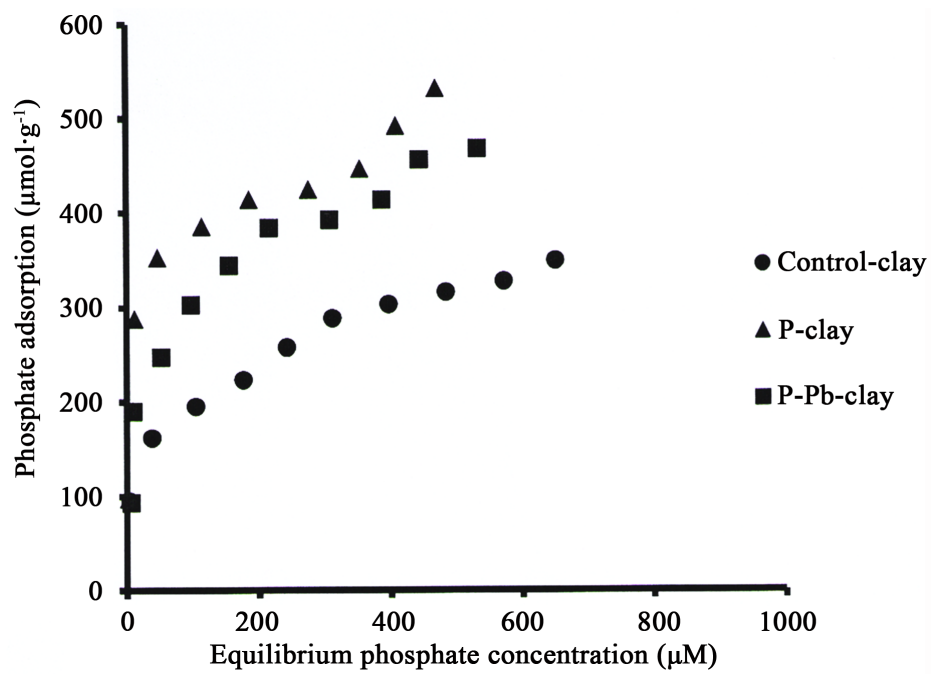

Figure 6. Phosphate adsorption isotherm by allophane (control), Pb-allophane and $\mathrm{P}-\mathrm{Pb}$-allophane. 
Phosphorus adsorption onto kaolinite may be via an inner-sphere mechanism and also by the formation of Al-P surface precipitates [47]. The reaction of phosphate with permanent charge minerals has received much less attention [49], and generally supposed that it occurs on edge, variable charge regions of the phyllosilicate [37] (Parfitt, 1978). Montmorillonite hardly adsorbs phosphates anions because of it is a lower amount of reactive sites such as $\mathrm{Al}-\mathrm{OH}$ [50] [51] [52].

The experiments data of adsorption isotherm of phosphate onto $\mathrm{Pb}$-pretreated on three sorbents (montmorillonite, allophane, and kaolinite) are shown in Figures 4-6. It is clearly evident that the amount of phosphate adsorption onto the $\mathrm{Pb}$-pretreated clay was higher than the $\mathrm{Pb}$-free clay in all cases. Phosphate minerals play a significant role in regulating the behavior and bioavailability of $\mathrm{Pb}$ in soils [53]. The adsorption of $\mathrm{Pb}$ first then phosphate may be $\mathrm{Pb}$ to a competitive interaction of phosphate with the montmorillonite- $\mathrm{Pb}$ complex on montmorillonite surface, which caused breaking of bonds between $\mathrm{Pb}$ and the surface and precipitation of pyromorphite. Since the amount of phosphate adsorbed on montmorillonite are usually lower than that found in $\mathrm{Pb}$ adsorption, it is expected that the effect of phosphate on $\mathrm{Pb}$ adsorption will not be as strong as observed in $\mathrm{Pb}$ on phosphate adsorption [49]. The increase of phosphate adsorption in $\mathrm{Pb}$-clay mineral ascribed partly to adsorption of phosphate in mineral and partly to the formation of pyromorphite which is highly stable [14] [54]. The amount of phosphate adsorption for the mixed system was lower than the single system. This indicates competitive adsorption between phosphate and $\mathrm{Pb}$ at pore region of allophane where both aluminol and silanol groups exposed.

The amount of phosphate onto simultaneous $\mathrm{Pb}$-phosphate-treated clays onto three mineral (montmorillonite, allophane, and kaolinite) are presented Figure 4-6. As shown in these figures, this treatment gave different amounts when they compared with the phosphate adsorption in Pb-pretreated mineral. The simultaneous montmorillonite had a greater $\mathrm{P}$ sorption than $\mathrm{P}$-free $\mathrm{Pb}$ and pre-treated with $\mathrm{Pb}$ (Figure 4 and Table 1). The phosphate adsorption was higher in kaolinite and lower in montmorillonite and allophane. Slightly more phosphate was adsorbed by simultaneously phosphate- $\mathrm{Pb}$-treated kaolinite than $\mathrm{Pb}$ pretreated kaolinite. Since $\mathrm{Pb}$ and phosphate tend to form $\mathrm{Pb}$-phosphate complexes in co-existing solution, it is likely that more complexes might be formed in the simultaneously treated system than the pretreated system. Therefore, in the simultaneously treated system, these complexes might be adsorbed by some sorption sites that differed from phosphate adsorbing sites in addition to phosphate specific adsorption. Thus, the overall phosphate adsorption was relatively higher in this system. When added simultaneously, the two ions were adsorbed about equally, with the total surface coverage being slightly greater than for either ion alone. Langmuir Xm values of phosphate were $145 \mathrm{mmol} \cdot \mathrm{kg}^{-1}$ on montmorillonite, and $385 \mathrm{mmol} \cdot \mathrm{kg}^{-1}$ on $\mathrm{Pb}$-pretreated montmorillonite (Table 2). The great increase in $\mathrm{Xm}$ value in the $\mathrm{Pb}$-pretreated montmorillonite was ascribed to the formation of highly stable $\mathrm{Pb}$-phosphate (pyromorphite) on the surface of 
montmorillonite. However, in the simultaneous adsorption experiments, Xm did not increased $\left(141 \mathrm{mmol} \cdot \mathrm{kg}^{-1}\right)$. This also indicates a need for the kinetic study suggested above. Therefore, there are three mechanisms to elucidate the amount of $\mathrm{Pb}$ in the simultaneous $\mathrm{Pb}$-phosphate-treated clay was slightly lower than that $\mathrm{P}$-mineral, in all cases, in the same time. The first is adsorption $\mathrm{Pb}$ on the clay pretreated surface, the second is partially due to (dissolution-precipitation mechanism) by the formation of Pyromorphite. Similar results were described by [41] [54] [55]. The third is maybe due to the complexes create a new surface and adsorption occur by some sorption sites that differed from phosphate adsorbing sites in addition to phosphate specific adsorption.

\section{Conclusion}

The adsorption and mutual adsorption isotherms of all three metal ions followed well Langmuir equation. The amount of adsorption of lead on all three minerals has been highest on montmorillonite followed by allophane and then kaolinite, these findings indicating that the clay minerals are important sinks for the lead in soils. The adsorption capacity of lead in clay pretreated phosphate enhance the adsorption, however, the enhancement depends on minerals type. So, clay pretreated phosphate was found to be very good sorbent for the lead for both allophane and kaolinite mineral, whereas adsorption enhancement is not observed onto montmorillonite, the enhancement may be due to increasing negative charge, causing a new surface. Thus, the addition of phosphate is suitable to remediate lead contamination soil, these especially strong in a site of lead contaminated sites especially dominate by both allophane and kaolinite. The order of addition of $\mathrm{Pb}$ and phosphate separately in clay pretreated phosphate or clay pretreated $\mathrm{Pb}$ or simultaneously addition, gave different amount of adsorption for both phosphate and lead in two systems onto three minerals, thus, extra information on kinetic study for all adsorbate on three minerals are needed. These findings suggesting the actual reactions are more complicated that could be only described by adsorption isotherm and Langmuir equation. Therefore, other techniques such as X-ray diffraction, Scanning Electron Microscopy with energy-dispersive X-ray analyses, and ATR-FTIR and more other highly sophisticated surface analytical performances are essential to find and elucidate the mechanisms of these reactions. Addition to this, more research will be necessary to explore the actual relationships between $\mathrm{Pb}$ and Phosphate to another type of clay minerals.

\section{References}

[1] Cruz-Guzman, M., Celis, R., Hermonsin, M.C., Koskinen, W.C., Nater, E.A. and Conejo, J. (2006) Heavy Metal Adsorption by Montmorillonites Modified with Natural Organic Cations. Soil Science of Society America Journal, 70, 215-221. https://doi.org/10.2136/sssaj2005.0131

[2] Tchounwou, P.B., Yedjou, C.G., Patlolla, A.K. and Sutton, D.J. (2012) Heavy Metal Toxicity and the Environment. Molecular, Clinical and Environmental Toxicology, 
101, 133-164. https://doi.org/10.1007/978-3-7643-8340-4_6

[3] Miller, H., Croudace, I.W., Bull, J.M, Cotterill, C.J., Dix, J.K. and Taylor, R.N. (2014) A 500-Year Sediment Lake Record of Anthropogenic and Natural Inputs to Windermere (English Lake District) Using Double-Spike Lead Isotopes, Radiochronology, and Sediment Microanalysis. Environmental Science and Technology, 48, 7254-7263. https://doi.org/10.1021/es5008998

[4] Ellis, B.G. and. Foth, H.D. (1996) Soil Fertility. 2nd Edition, CRC Press, Boca Raton.

[5] Huang, P.M., Li, Y. and Sumner, M.P., Eds. (2012) Handbook of Soil Sciences, Properties and Processes. 2nd Edition, CRC Press, Boca Raton.

[6] Parfitt, R.L. and Henmi, T. (1980) Structure of Some Allophanes from New Zealand. Clays and Clay Minerals, 28, 285-294. https://doi.org/10.1346/CCMN.1980.0280407

[7] Bhattacharyya, K.G. and Gupta, S.S. (2008) Adsorption of a Few Heavy Metals on Natural and Modified Kaolinite and Montmorillonite, a Review. Advances in Colloid and Interface Science, 140, 114-131. https://doi.org/10.1016/j.cis.2007.12.008

[8] Gupta, S.S. and Bhattacharyya, K.G. (2012). Adsorption of Heavy Metals on Kaolinite and Montmorillonite, a Review. Physical Chemistry Chemical Physics, 14, 6698-6723. https://doi.org/10.1039/c2cp40093f

[9] Kalantari, K., Ahmad, M.B., Masoumi, H.R.F., Shameli, K., Basri, M. and Khandanlou, R. (2015) Rapid and High Capacity Adsorption of Heavy Metals by $\mathrm{Fe}_{3} \mathrm{O}_{4} /$ Montmorillonite Nanocomposite Using Response Surface Methodology, Preparation, Characterization, Optimization, Equilibrium Isotherms, and Adsorption Kinetics Study. Journal of the Taiwan Institute of Chemical Engineers, 49, 192-198. https://doi.org/10.1016/j.jtice.2014.10.025

[10] Traina, S.J. and Laperche, V. (1999) Contaminant Bioavailability in Soils, Sediments, and Aquatic Environments. Proceedings of the National Academy of Sciences, USA, 96, 3365-3371. https://doi.org/10.1073/pnas.96.7.3365

[11] Wang, K. and Xing, B. (2002) Adsorption and Desorption of Cadmium by Goethite Pretreated with Phosphate. Chemosphere, 48, 665-670. https://doi.org/10.1016/S0045-6535(02)00167-4

[12] Wang, K. and Xing, B. (2004) Mutual Effects of Cadmium and Phosphate on Their Adsorption and Desorption by Goethite. Environmental Pollution, 127, 13-20. https://doi.org/10.1016/S0269-7491(03)00262-8

[13] Miretzky, P. and Fernandez-Cirelli A. (2008) Phosphates for Pb Immobilization in Soils: A Review. Environmental Chemistry Letters, 6, 121-133. https://doi.org/10.1007/s10311-007-0133-y

[14] Patricia, M. and Alicia, F. (2008) Phosphates for Pb Immobilization in Soils: A Review. Environmental Chemistry Letters, 6, 121-133. https://doi.org/10.1007/s10311-007-0133-y

[15] Adebowale, K.O., Unuabonah, I.E. and Olu-Owolabi, B.I. (2005) Adsorption of Some Heavy Metal Ions on Sulfate- and Phosphate-Modified Kaolin. Applied Clay Science, 29, 145-148. https://doi.org/10.1016/j.clay.2004.10.003

[16] Unuabonah, E.I., Adebowale, K.O. and Olu-Owolabi, B.I. (2007) Kinetic and Thermodynamic Studies of the Adsorption of Lead (II) Ions onto Phosphate-Modified Kaolinite Clay. Journal of Hazardous Materials, 144, 386-395. https://doi.org/10.1016/j.jhazmat.2006.10.046

[17] Ranatunga, T.D., Taylor, R.W. Schulthess, C.P. Ranatunga, D.R.A., Bleam, W.F. and Senwo, Z.N. (2008) Lead Sorption On Phosphate-Pretreated Kaolinite, Modeling, 
Aqueous Speciation, and Thermodynamincs. Soil Science, 173, 321-331. https://doi.org/10.1097/SS.0b013e31816d1e25

[18] Henmi, T. and Wada, K. (1976) Morphology and Composition of Allophane. American Mineralogist, 61, 379-390.

[19] Higashi, T. and Ikeda, H. (1974) Dissolution of Allophane by Acid Oxalate Solution. Clay Science, 4, 205-211.

[20] Murphy, J. and Riley, J.P. (1962) A Modified Single Solution Method for Determination of Phosphate in Natural Waters. Analytica Chimica Acta, 27, 31-36. https://doi.org/10.1016/S0003-2670(00)88444-5

[21] Abd-Elfattah, A. and Wada, K. (1981) Adsorption Lead, Copper, Zinc, Cobalt, and Cadmium by Soils That Different in Cation-Exchange Materials. Journal of Soil Science, 32, 271-283. https://doi.org/10.1111/j.1365-2389.1981.tb01706.x

[22] Esfandbod, M., Forghani, A., Adhami, E. and Rezaei Rashti, M. (2011) The Role of $\mathrm{CEC}$ and $\mathrm{pH}$ in Cd Retention from Soils of North of Iran. Soil and Sediment Contamination: An International Journal, 20, 908-920.

https://doi.org/10.1080/15320383.2011.620044

[23] Ramachandran, V. and D’Souza, S.F. (2013) Adsorption of Nickel by Indian Soils. Journal of Soil Science and Plant Nutrition, 13, 165-173. https://doi.org/10.4067/S0718-95162013005000015

[24] Dai, Z., Meng, J., Shi, Q., Xu, B., Lian, Z., Brookes, P.C. and Xu, J.M. (2015) Effects of Manure- and Lignocellulose-Derived Biochars on Adsorption and Desorption of Zinc by Acidic Types of Soil with Different Properties. European Journal of Soil Science, Special Issue on Including Landmark Papers, 67, 40-50.

[25] Appel, C. and Ma, L. (2002) Concentration, pH, and Surface Charge Effects on Cadmium and Lead Sorption in Three Tropical Soils. Journal of Environmental Quality, 31, 581-589. https://doi.org/10.2134/jeq2002.5810

[26] Veeresh, H., Tripathy, S., Chandhuri, D., Hart, B.R. and Powell, M.A. (2003) Sorption and Distribution of Adsorbed Metals in Three Soils of India. Applied Geochemistry, 18, 1723-1731. https://doi.org/10.1016/S0883-2927(03)00080-5

[27] Schindler, P.W., Leichti, P. and Westall, J.C. (1987) Adsorption of Copper, Cadmium and Lead from Aqueous Solution to the Kaolinite/Water Interface. Netherlands Journal of Agricultural Science, 35, 219-230.

[28] Pulse, R.W., Powell, R.M., Clar, D. and Eldred, C. (1991) Effects of Soil/Solution Ratio, Ionic Strength, and Organic Acids on $\mathrm{Pb}$ and $\mathrm{Cd}$ Sorption on Kaolinite. Water, Air, and Soil Pollution, 57-58, 423-430. https://doi.org/10.1007/BF00282905

[29] Gräfe, M., Singh, B. and Balasubramanian, M. (2007) Surface Speciation of Cd(II) and $\mathrm{Pb}(\mathrm{II})$ on Kaolinite by XAFS Spectroscopy. Journal of Colloid and Interface Science, 315, 21-32. https://doi.org/10.1016/j.jcis.2007.05.022

[30] Heidmann, I., Christl, I., Leu, C. and Kretzschmar, R. (2005) Competitive Sorption of Protons and Metal Cations onto Kaolinite, Experiments and Modeling. Journal of Colloid and Interface Science, 282, 270-282. https://doi.org/10.1016/j.jcis.2004.08.019

[31] Ghoniem, A.M., Matsue, N. and Henmi, T. (2002) Adsorptive Mechanism of Copper and Zinc on Nano-Ball Allophone. Clay Science, 11, 615-624.

[32] Sposito, G. (1989) The Chemistry of Soils. Oxford University Press, New York.

[33] Sparks, D.L. (1995) Environmental Soil Chemistry. Academic Press, San Diego, CA.

[34] Sparks, D.L., Scheidegger, A.M., Strawn, D.G. and Scheckel, K.G. (1998) Kinetics and Mechanisms of Reactions at the Mineral/Water Interface. In: Sparks, D.L. and 
Grundl, T.J., Eds., Mineral- Water Interfacial Reactions. Reactions and Mechanisms, American Chemical Society Symposium Series, American Chemical Society Washington, DC, 32.

[35] Strawn, D.G. and Sparks, D.L. (1999) The Use of XAFS to Distinguish between Inner- and Outer-Sphere Lead Adsorption Complexes on Montmorillonite. Journal of Colloid and Interface Science, 216, 257-269.

https://doi.org/10.1006/jcis.1999.6330

[36] Li, W. Zhang, S., Jiang, W. and Xiao-Quan, S. (2006) Effect of Phosphate on the Adsorption of $\mathrm{Cu}$ and $\mathrm{Cd}$ on Natural Hematite. Chemosphere, 63, 1235-1241. https://doi.org/10.1016/j.chemosphere.2005.10.028

[37] Parfitt, R.L. (1978) Anion Adsorption by Soils and Soil Materials. Advances in Agronomy, 30, 1-50.

[38] Johan, E., Matsue, N. and Henmi, T. (1999) New Concepts for Change in Charge Characteristics of Allophane with Phosphate Adsorption. Clay Science, 10, 457-468.

[39] Xiong, L.M. (1995) Influence of Phosphate on Cadmium Adsorption by Soils. Fertilizer Research, 40, 31-40. https://doi.org/10.1007/BF00749860

[40] Manecki, M., Bogucka, A., Bajda, T. and Borkiewicz, O. (2006) Decrease of Pb Bioavailability in Soils by Addition of Phosphate Ions. Environmental Chemistry Letters, 4, 178-181. https://doi.org/10.1007/s10311-005-0030-1

[41] Bajda, T., Marchlewski, T. and Manecki, M. (2011) Pyromorphite Formation from Montmorillonite Adsorbed Lead. Mineralogia, 42, 75-91. https://doi.org/10.2478/v10002-011-0008-5

[42] Arai, Y. and Sparks, D.L. (2007) Phosphate Reaction Dynamics in Soils and Soil Minerals: A Multiscale Approach. Advances in Agronomy, 94, 135-179. https://doi.org/10.1016/S0065-2113(06)94003-6

[43] Beck, M.A., Robarge, W.P. and Buol, W. (1999) Phosphorus Retention and Release of Anions and Organic Carbon by Two Andisols. European Journal of Soil Science, 50, 157-164. https://doi.org/10.1046/j.1365-2389.1999.00213.x

[44] Johan, E., Matsue, N. and Henmi, T. (1997) Phosphate Adsorption on Nano-Ball Allophane and Its Molecular Orbital Analysis. Clay Science, 10, 259-270.

[45] Elsheikh, M.A., Abidin, Z. Matsue, N. and Henmi, T. (2008) Competitive Adsorption of Oxalate and Phosphate on Allophane at Low Concentration. Clay Science, 13, 181-188.

[46] Elsheikh M.A., Matsue, N. and Henmi, T. (2009) Effect of Si/Al Ratio of Allophane on Competitive Adsorption of Phosphate and Oxalate. International Journal of Soil Science, 4, 1-13.

[47] Kasama, T., Watanabe, Y. and Yamada, H. (2004) Sorption of Phosphates on Al-Pillared Smectites and Mica at Acidic to Neutral pH. Applied Clay Science, 25, 167-177. https://doi.org/10.1016/j.clay.2003.09.005

[48] Henmi, T. and Huang, P.M. (1985) Removal of Phosphorus by Poorly Ordered Clays as Influence by Heating and Grinding. Applied Clay Science, 1, 133-144. https://doi.org/10.1016/0169-1317(85)90569-1

[49] Madrid, L., Diaz-Barrientos E. and Contreras, M.C. (1991) Relationships between Zinc and Phosphate Adsorption on Montmorillonite and an Iron Oxyhydroxide. Australian Journal of Soil Research, 29, 239-247. https://doi.org/10.1071/SR9910239

[50] Fox, I. and Malati, M.A. (1993) An Investigation of Phosphate Adsorption by Clays and Its Relation to the Problem of Eutrophication of the River Stour, Kent. Journal of Chemical Technology and Biotechnology, 57, 97-107. 
https://doi.org/10.1002/jctb.280570202

[51] Tang, W.P., Shima, O., Ookubo, A. and Ooi, K. (1997). A Kinetic Study of Phosphate Adsorption Byboehmite. Journal of Pharmaceutical Sciences, 86, 230-235. https://doi.org/10.1021/js960232p

[52] Lookman, R., Grobet, P., Merckx, R. and Van Riemsdijk, W.H. (1997) Application of ${ }^{31} \mathrm{P}$ and ${ }^{27} \mathrm{Al}$ MAS NMR for Phosphate Speciation Studies in Soil and Aluminium Hydroxides, Promises and Constraints. Geoderma, 80, 369-388.

https://doi.org/10.1016/S0016-7061(97)00061-X

[53] Ma, Q.Y., Traina, S.J., Logan, T.J. and Ryan, J.A. (1993) In Situ Lead Immobile Immobilization by Apatite. Environmental Science and Technology, 27, 1803-1810. https://doi.org/10.1021/es00046a007

[54] Elouear, Z., Bouzid, J., Boujelben, N., Feki, M., Jamoussi, F. and Montiel, A. (2008) Heavy Metal Removal from Aqueous Solutions by Activated Phosphate Rock. Journal of Hazardous Materials, 156, 412-420.

https://doi.org/10.1016/j.jhazmat.2007.12.036

[55] Abdallah, S.M. (2014) Towards a Safer Environment: (9) Remediation of Heavy Metals from Low Quality Water in Asir Region, Southwestern Saudi Arabia. Journal of Novel Applied Sciences, 3, 1250-1258. 